Z Dmitrijem Bykowem

rozmawiają Grzegorz Przebinda i Bartosz Gołąbek

Krosno, maj 2014

\title{
Putin - przeciętny menedżer z KGB
}

Grzegorz Przebinda, Bartosz Gołąbek: W artykule Wielkie oszustwo naszych czasów (1896) Konstantin Pobiedonoscew ${ }^{1}$, patrząc na Rosję i Europę z pozycji antydemokratycznych, pisze: „Jedną z najbardziej oszukańczych zasad politycznych jest demokracja, idea rewolucyjna - zakorzeniona, niestety, już od czasów Wielkiej Rewolucji Francuskiej, według której wszelka władza pochodzi od ludu i ma swe oparcie w woli tegoż ludu. Stąd również pochodzi teoria parlamentaryzmu, która aż do dziś wodzi na pokuszenie masę tak zwanej inteligencji i - na nieszczęście - przedostała się także do szalonych głów Rosji”... Władimir Putin, jak się wydaje, pragnie - z jednej strony - wcielić w życie ów antyliberalny, polityczny projekt Pobiedonoscewa, ale zarazem w drugiej połowie 2014 roku ma on przecież poparcie ponad osiemdziesięciu procent Rosjan. Czyżby syndrom sztokholmski?

Jak dobrze wiecie, historia Rosji powtarza się stale według tego samego schematu. Człowiek pojawia się tutaj w takiej roli, jaką mu historia przypisała. Gdyby Putin

1 Konstantyn Pobiedonoscew (1827-1907) - rosyjski polityk z czasów Aleksandra III i młodego Mikołaja II. W latach I880-I905 oberprokurator (zwierzchnik) Świątobliwego Synodu, organu świeckiego zarządzającego Cerkwią od czasów Piotra Wielkiego (I723), po wcześniejszej likwidacji patriarchatu (I700). Pobiedonoscew był znany z reakcjonizmu, słynna jest jego, często i dziś przytaczana, fraza: „Trzeba podmrozić Rosje, aby nie gnita”. Ten przypis i wszystkie poniższe Grzegorz Przebinda. 
pozostał uczniem Aleksandra Sobczaka ${ }^{2}$, jakim przecież był, to dziś funkcjonowałby on jako liberał. Ale życie przypisało mu rolę Napoleona, który znacznie łagodnieje po rewolucji, i dziś Putin taką właśnie rolę odgrywa. Rosją nigdy nie rządzi osoba, istnieją tutaj tylko role i funkcje. Historia jest u nas cykliczna, powtarza się niemal dosłownie, to jest też odrębny temat. Ale mówiąc ogólnie, dzieje się tak dlatego, że naród uczestniczy w historii w sposób naprawdę minimalny. Rosyjski naród czyni wszystko, aby strząsnąć z siebie historyczną odpowiedzialność. Najpierw ubóstwia wodza, aby później obwiniać go o wszystko. Dokładnie ta sama historia powtarza się z Putinem. Teraz wszyscy go ubóstwiają, a za rok czy dwa będą mówić „Och, jak bardzo byliśmy w błędzie, a już Władimir Władimirowicz... Ten, to dopiero się mylił..." I za wszystko będzie obwiniany właśnie on... Putin absolutnie nie jest dyktatorem z natury, obce jest mu to uczucie, które białoruski pisarz Aleś Adamowicz ${ }^{3}$ w swej książce Oprawcy określił jako „radość noża”. Obce mu jest owo zadowolenie z siebie, jakie odczuwa kat. Jest zwykłym menedżerem, wychowanym w KGB, który cały czas pragnie przypodobać się swym przełożonym. A jest to bardzo poważne zadanie dla tak mało znaczącego urzędnika. Zresztą jego wyobrażenia o przełożonych też się zmieniają. W pewnym momencie sądził, że należy przypodobać się Stanom Zjednoczonym. Zadzwonił wtedy, po II września 20or roku, do Busha, zaoferował pomoc, czynił wszystko, co w jego mocy, by przypodobać się Zachodowi ${ }^{4}$. Potem jednak wydawało mu się, że trzeba się przypodobać swemu narodowi, bo może jednak naród ten o czymś decyduje... I bez przerwy jeździł po kraju, rozmawiał z ludźmi, uprawiał beznadziejny populizm... Teraz znowu uważa, że powinien przypodobać

2 Aleksander Sobczak (1937-2000) - prawnik i polityk, współpracownik Michaiła Gorbaczowa podczas „pieriestrojki”. W I99I wybrany w powszechnych wyborach na pierwszego prezydenta (mera) Leningradu, który odzyskał właśnie wtedy swą pierwotną nazwę Sankt-Petersburg. Urząd sprawował do 1996, przegrywając już następne wybory. Putin w I99I-1996 był jego zastępcą. Jednak od 1996 ich losy potoczyły się skrajnie odmiennie - Sobczak został oskarżony o korupcję i musiał nawet przez dwa lata chronić się we Francji (formalnie przebywał na leczeniu), podczas gdy Putin przeprowadził się na zawsze do Moskwy, robiąc tam błyskawiczną karierę przy prezydencie Borysie Jelcynie (193I-2007). Druga kadencja Jelcyna nie została dokończona, gdyż 3I grudnia I999 zrzekł się on urzędu i przekazał „obowiązki prezydenta” właśnie Putinowi. Por. G. Przebinda, J. Smaga, Kto jest kim w Rosji po I9I7 roku, Znak, Kraków 2000, s. 259.

3 Aleksander (Ałeś) Adamowicz (1927-1994) - białoruski pisarz, scenarzysta filmowy, literaturoznawca, podejmujący stale tematykę II wojny światowej. Pisał zarówno po rosyjsku, jak i po białorusku. Najważniejsze dzieła: Ja ze spalonej wsi (1977, przekład polski: 1978), Oprawcy (1980, przekład polski: 1988), Księga blokady, wespół z Danielem Graninem (1977-1981, przekład polski: 1982). Był współautorem scenariusza do wstrząsającego filmu fabularnego Idź i patrz (1985, reż. Elem Klimow), opowiadającego o zagładzie wsi białoruskich podczas okupacji niemieckiej. Inspiracją dla tego filmu była m.in. Chatyńska opowieść Adamowicza o zagładzie białoruskiej wsi Chatyń. Swoją drogą, radzieccy komuniści - ze względu na zbieżność nazw - próbowali wykorzystać tę bezprzykładną zbrodnię Niemców na Białorusinach do przykrycia własnej straszliwej zbrodni, dokonanej przez Sowietów na Polakach w Katyniu.

4 Mowa tu oczywiście o zamachu na World Trade Center w Nowym Jorku II IX 20or i o natychmiastowej telefonicznej rozmowie Putina z prezydentem George’m Bushem (1924-20I8), podczas której prezydent Rosji - jako pierwszy zagraniczny polityk - wyraził Amerykanom głębokie współczucie. 
się Chinom i działa w ten sam sposób. Wie, jak się podobać, potrafi zawsze znaleźć wspólny język z rozmówcą. Ale nie ma absolutnie pojęcia o sprawach ogólnych, a to, co mówi teraz o rosyjskim filozofie i monarchiście Iwanie Iljinie ${ }^{5}$, czy - dajmy na to - że co jakiś czas odwołuje się do rosyjskiej filozofii konserwatywnej, to wcale nie wynika z jego wewnętrznych przekonań. Cokolwiek mu podsuną, na to się powołuje. Dokładnie tak samo powoływałby się na Nikołaja Bierdiajewa ${ }^{6}$, gdyby zaszła taka potrzeba... A w gruncie rzeczy, główny rosyjski spór dotyczy kwestii poruszanych w dyskusji Iljina z Bierdiajewem - o sposobach „przeciwstawiania się złu”. Putin odwołuje się do Iljina, zwolennika siły. A powinien odwołać się jednak do Bierdiajewa.

\section{Ale przecież Putin i jego otoczenie odwołują się właśnie do jednej z książek Bier- diajewa - do jego Filozofii nierówności (1918), będącej pochwałą konserwatyzmu i antyrewolucjonizmu. Stosunek Putina do komunizmu wydaje się być dwojaki. Chce on chyba z jednej strony odrzucić politykę Lenina i wczesnych bolszewi- ków za to, że zniszczyli imperium, oddając na przykład „Noworosję" Ukrainie. I boi się teraz jakiejś rewolucji w Rosji, nie chce, żeby doszło do jakiegokolwiek przewrotu. Po drugie zaś, Stalina ceni, choć nigdy nie wypowiada tego otwarcie.}

5 Iwan Iljin (1883-1954) - rosyjski filozof konserwatywny, monarchista. W 1922, wraz z grupą innych filozofów, wydalony z bolszewickiej Rosji. W 1925 wydał głośną książkę O sprzeciwianiu się ztu sita, w której odrzucił zarówno ateistyczną doktrynę rosyjskiej lewicowej inteligencji wraz z bolszewizmem, jak i system etyczny Lwa Tołstoja, potępiającego wszelką przemoc. Obu tym skrajnościom przeciwstawiał „prawosławną tradycję rycerską”. Por. G. Przebinda, J. Smaga, dz. cyt., s. Io8. Do I990 w ZSRR o Iljinie prawie nie mówiono, jednak w latach 1993-2008 ujrzało światło dzienne aż dwadzieścia osiem tomów wyboru jego dzieł. W październiku 2005 prochy filozofa i jego żony Natalii zostały przeniesione z Zollikonu koło Zurychu w Szwajcarii na cmentarz przy Monasterze Dońskim w Moskwie. Myśliciel cieszy się obecnie popularnością zarówno wśród hierarchów Rosyjskiej Cerkwi Prawosławnej, jak i u prezydenta Putina. Amerykański historyk Timothy Snyder w książce Droga do niewolności (2019) przypisuje Iljinowi - moim zdaniem, nazbyt pochopnie sympatie faszystowskie i w tym widzi głównie jego wpływ na Putina.

6 Nikołaj Bierdiajew (I874-I948) - rosyjski filozof religijny, przeszedł ewolucję od marksizmu do idealizmu, od 1922, po wyrzuceniu z ZSRR, na emigracji w Berlinie, a ostatecznie - we Francji. W Filozofi nierówności, napisanej jeszcze przed emigracją, odrzucił z pozycji arystokratycznych egalitarne ideały bolszewizmu. W Berlinie opublikował słynne Nowe średniowiecze (1924), głoszące apologię życia archaicznego w małych wspólnotach religijnych, bez jakiejkolwiek polityki. Por. G. Przebinda, J. Smaga, dz. cyt., s. 32-33.

7 Noworosja - rozległy region historyczno-kulturowy w północnym regionie Morza Czarnego, włączony do imperium rosyjskiego w wyniku wojen rosyjsko-tureckich za Katarzyny II, w drugiej połowie XVIII wieku, z takimi miastami jak - Jekaterynosław (obecnie Dniepr), Cherson, Nikołajewsk, Odessa (obecnie wszystkie w Ukrainie). W ZSRR cała „Noworosja” należała do Ukraińskiej Socjalistycznej Republiki Radzieckiej (Krym - od 1954). W 20I4, po aneksji Krymu przez Putina, termin nabrał nowego, imperialistycznego - ze strony rosyjskiej - znaczenia. Prorosyjscy włodarze samozwańczych, nieuznawanych w cywilizowanym świecie Donieckiej i Ługańskiej Republik Ludowych ogłosili konieczność odebrania „Noworosji” Ukrainie i przyłączenie jej do Rosji. Na wschodzie Ukrainy działał nawet wówczas pod historyczną nazwą „Noworosja” prorosyjski konfederacyjny związek, zamrożony jednak formalnie w 20I5 roku po rosyjsko-ukraińskich pokojowych Porozumieniach Mińskich. 
Gdy dziś czytamy Filozofię nierówności Bierdiajewa, to odnajdujemy tam nie tylko potępienie rewolucji, ale również pogląd, że historią rządzi wykształcona mniejszość, a Putin oczywiście do niej przynależy. Ale wydaje się, że Putin ze swym otoczeniem niepotrzebnie odwołują się do arystokratycznej Filozofii nierówności, powinni się odwoływać do Nowego średniowiecza Bierdiajewa, swego rodzaju ,apologii mas” w duchu Ortegi y Gasseta.

Tak, oczywiście. Ale powtarzam, jest mu całkowicie obojętne, na co się powołuje. Musimy to zrozumieć. Łotrem jednak nie jest. Gdy Stalin rozkoszował się krwawymi procesami, czynił to jako mściwy góral z Kaukazu... Kaukaski duch ma notabene wiele wspólnego z polskim - mam tu na myśli maleńkie państwo, ale z wielką dumą...

Polacy walczyli ramię w ramię z ludami Kaukazu przeciwko carskiej Rosji. Innych sojuszników wtedy nie mieliśmy.

Jasne, wiem o tym. Już Aleksander Dumas pisał, że Rosja musi utracić i Kaukaz, i Polskę... Dlatego też, dodajmy, zsyłano Polaków na Syberię albo Rosjan na Kaukaz. To takie dwie skrajne przestrzenie Rosji. Ale wróćmy do Putina - on nie ma żadnej ideologii. Próba Aleksieja Czadajewa ${ }^{8}$, aby napisać pracę o ideologii Putina, zupełnie się nie powiodła. Takiej ideologii nie ma.

\section{Powstała nawet taka praca?}

Tak, istnieje praca Czadajewa Putin. Jego ideologia9. Mówiono nawet, by Czadajew zmienił nazwisko, bo hańbi swego dalekiego przodka, Piotra Czaadajewa ${ }^{10}$. Putin żadnej ideologii nie zrealizował. Państwowość, suwerenność to jeszcze nie jest ideologia. Ale on naprawdę szczerze nienawidzi Lenina, chce go nawet usunąć z Mauzoleum.

Ale nie mówi o tym otwarcie. Może dlatego, że nie chce stracić zwolenników?

Zdecydowanie chce go usunąć z Mauzoleum, ale odkłada ten krok do momentu, gdy będzie trzeba odwrócić uwagę ludzi od kryzysu. Wtedy Lenin zostanie usunięty... Rzecz w tym, że większość Rosjan jest nastawiona do Lenina - inaczej niż do Stalina - bardzo sceptycznie. Z dwóch powodów. Po pierwsze, Lenina mimo wszystko zalicza się do warstwy wykształconej, a ponadto miał on w swych żyłach dwadzieścia

8 Aleksiej Czadajew (ur. 1978) - rosyjski dziennikarz, politolog, działacz społeczny, we wspomnianej niżej książce dokonał próby konstrukcji ideologii Putina na podstawie jego przemówień i wystąpień publicznych.

9 А. Чадаев, Путин. Его идеология, Европа, Москва 2006.

10 Piotr Czaadajew (I794-I856) - znany rosyjski myśliciel religijny pierwszej połowy XIX w., bardzo krytyczny wobec historii i współczesności carskiej Rosji, autor m.in. Listów fllozoficznych, napisanych w I828-I830. Po publikacji w I836 pierwszego i najbardziej skandalicznego z punktu widzenia władzy listu został uznany za obłąkanego i osadzony w areszcie domowym. Por. G. Przebinda, $\mathrm{Od}$ Czaadajewa do Bierdiajewa. Spór o Boga i cztowieka w myśli rosyjskiej (I832-I922), Polska Akademia Umiejętności, Kraków I998, s. 83-I43. 
pięć procent krwi żydowskiej, co w Rosji jest niewybaczalne. Po drugie, Lenin to przecież rewolucjonista, w jego ideologii nie ma nic z imperializmu. Wszyscy znają jego artykuł $O$ dumie narodowej Wielkorusów, napisany w Bernie w Szwajcarii w I9I4 roku. Lenin nienawidzi rosyjskiego szowinizmu, widzi w nim przede wszystkim przejaw złego gustu. Powiem teraz coś ryzykownego - Lenina jako krytyka literackiego trzeba jednak traktować poważnie. Coś jednak z literatury rozumiał, a przynajmniej gust miał dobry. W odróżnieniu od Stalina, którego gust był jawnie plebejski.

\section{Muzykę Stalin lubił tylko ludową, taką melodyjną kantylenkę...}

Stalin przynajmniej rozumiał, że Szostakowicz ma talent..., ale niechże tworzy bardziej melodyjnie, w stylu Pieśni o lasach. Ale już dobrze znana Katarzyna Izmajtowa to „chaos zamiast muzyki" . Stalin był człowiekiem o bardzo kiepskim guście. A Lenin gust posiadał i rozumiał, że wielkoruska ideologia, kultura wielkoruska, te wszystkie szowinistyczne próby pseudofilozofowania mają w sobie coś z mauvais ton ${ }^{12}$, są w bardzo złym guście. I dlatego jest dziś postrzegany przez większość ludności Rosji jako wielki destabilizator.

\section{Czyżby wielbiciele Lenina już powymierali? A pamiętasz, ilu ich jeszcze było w latach dziewięćdziesiątych?}

Tak, praktycznie powymierali. Ale i nawet wtedy nie byli to wielbiciele Lenina, lecz zwolennicy „projektu radzieckiego”. A dziś Stalin jest słusznie postrzegany przez wielu jako anty-Lenin. Jegor Jakowlew ${ }^{13}$, co prawda, zawsze powtarzał, że przeceniamy intelekt Lenina - a robimy to dlatego, że Lenin zwalczał „kult jednostki”. Ale obecnie także i ja, co może się wam wydać dziwne, występuję od czasu do czasu w obronie Lenina. Dodam, że i dla mnie jest to sposób wyrażenia sprzeciwu wobec kultu Stalina.

11 Dmitrij Szostakowicz (1906-1975) - kompozytor rosyjski okresu ZSRR, jeden z największych symfonistów XX wieku. Mimo ugruntowanej pozycji w kraju, w czasach Stalina bywał parokrotnie potępiany za antytradycjonalizm, nadmierne nowatorstwo i polemiczne wobec słodkiego socrealizmu tony. Jeszcze w 1932 ukończył operę Lady Makbet mceńskiego powiatu, według opowiadania Nikołaja Leskowa, wystawianą z sukcesem w Szwecji, Czechosłowacji, Anglii i Danii. Gdy jednak w 1936 moskiewską premierę spektaklu w Teatrze Wielkim obejrzeli Stalin wraz z Aleksandrem Żdanowem sukces zamienił się w totalną klęskę. Już nazajutrz w „Prawdzie” ukazał się redakcyjny artykuł Chaos zamiast muzyki, potępiający „formalizm” $i$ „wulgarny naturalizm” tego dzieła. Potem jeszcze raz po wojnie, w 1948, Szostakowicz został potępiony z kolei za IX Symfonię, ale potrafil się skutecznie pokajać socrealistycznym oratorium Pieśn o lasach i muzyką do filmu Upadek Berlina (1949), za które w 1950 otrzymał czwartą już Nagrodę Stalinowską. W I962 przerobił Lady Makbet... i nadał jej nowy tytuł Katarzyna Izmajtowa. Por. G. Przebinda, J. Smaga, dz. cyt., s. 284-285.

12 mauvais ton (fr.) - zły gust.

13 Jegor Jakowlew (1930-2005) - dziennikarz, pisarz, polityk, jedna z czołowych postaci „pieriestrojki” Michaiła Gorbaczowa, był m.in. redaktorem naczelnym liberalnego w późnym ZSRR tygodnika „Moskowskije Nowosti” oraz wydawanego już w Federacji Rosyjskiej dziennika „Obszczaja Gazieta”. W 1988 opublikował Dzień i życie. Notatki do biografii Wtadimira Iljicza. 


\section{A gdyby nie to, odrzuciłbyś także i Lenina?}

Wiecie... Mój stosunek do niego prosty nie jest... Lenin to przynajmniej jakiś myśliciel. Choć Konstantin Michajłow ${ }^{14}$, znaczący badacz Lenina, twierdzi, że on w ogóle nie był filozofem, lecz tylko politykiem o określonych poglądach. Ja jednak uważam, że Lenin filozofem był. Jego optymistyczna filozofia wychodziła z założenia, że świat podlega przebudowie. Filozofia stalinowska natomiast opierała się na przekonaniu, że należy wykorzystywać najgorsze cechy narodu, podczas gdy Lenin uważał, że takie cechy należy wykorzeniać. Lenin odrzucał model narodowy, a Stalin go wzmacniał. Lenin dlatego postradał zmysły, bo widział, że nieomal na jego oczach odbudowało się imperium, które on chciał zniszczyć.

Gdy zaś chodzi o Putina, to dla niego nie jest ważne, jakiej idei bronić. Należy on do klasy zarządzającej, jest człowiekiem, na nasze szczęście, nieskorym do przelewu krwi, jego poglądy, dość prymitywne, mieszczą się w sferze czysto organizacyjnej. Zwróćcie uwagę, że wysłali na Krym całkiem sporo przeróżnych postaci, działała tam przecież nie tylko armia. Także i tak zwani „pasjonariusze”15, którzy chcą sobie powalczyć... Putin wysłał tam - albo i nie on, lecz jego administracja - wielu ludzi, którzy wcześniej byli powiązani z Eduardem Limonowem ${ }^{16}$, na przykład taki Aleksander Borodaj... ${ }^{17}$ Wysłał tam również, dodajmy, ludzi, którzy zajmują się historią wojskowości, rekonstrukcjami historycznymi, takich jak Igor Girkin (Striełkow) ${ }^{18}$.

14 Konstantin Michajłow (ur. 1965) - dziennikarz i historyk, autor cyklu arcyważnych książek poświęconych niszczeniu historycznej Moskwy przez bolszewików (w tym osobiście przez Lenina) i w czasach już nam współczesnych - Zniszczony Kreml, Moskwa, która zginęta (lata 19I7-2007), Zburzone świątynie Moskwy. Na zgliszczach Trzeciego Rzymu (wszystkie w 2007), Moskwa, która utraciliśmy (2010).

15 „Pasjonariusze” - ludzie przeniknięci ideą czynu, którzy chcą zmieniać gruntownie historię, w tym i zastaną rzeczywistość. Termin ów został ukuty przez Lwa Gumilowa (1912-1992) w pracy Etnogeneza i biosfera ziemi, gdzie jest mowa o procesie historycznym jako wzajemnym wpływie i rywalizacji etnosów (narodów), ukształtowanych pierwotnie w środowisku geograficznym. Dzisiaj „teorię pasjonarności” wykorzystują w Rosji głównie ci, którzy postulują odrodzenie imperium rosyjskiego w jego radzieckim albo nawet jeszcze w szerszym - carskim kształcie. Por. B. Gołąbek, Lew Gumilow i Aleksander Dugin. O dwóch obliczach eurazjatyzmu w Rosji po Ig9r roku, Seria Barwy Rusi, WUJ, Kraków 20I2, s. 73-89.

16 Eduard Limonow (1943-2020) - rosyjski pisarz, publicysta, działacz polityczny o skrajnie nacjonalistycznych przekonaniach. W I974-I99I na emigracji, w 1979 wydał w Nowym Jorku skandalizująca książkę To ja, Ediczka z elementami twardej pornografii. Po powrocie do nowej Rosji założył w 1993 w Moskwie Partię Narodowo-Bolszewicką (od 2010 - Inna Rosja), wydawał także w 1994-2002 ekstremistyczną gazetę „Limonka” („Granat”). Był zagorzałym przeciwnikiem neoliberalnych reform w Rosji Jelcyna, a już w czasach wczesnoputinowskich (200I) został aresztowany i skazany za posiadanie broni. W 2014 gorąco poparł jednak aneksję Krymu i postulował zajęcie przez Rosję całej pozostałej Ukrainy wschodniej z Kijowem.

17 Aleksander Borodaj (ur. 1972) - obywatel Rosji, w 20I2-20I4 premier samozwańczej, separatystycznej i prorosyjskiej Donieckiej Republiki Ludowej na wschodzie Ukrainy (istnieje formalnie od I2 V 20I4). W 1993 walczył po stronie Rady Najwyższej w jej zbrojnym konflikcie z Jelcynem. Dziś mieszka w Moskwie, przewodzi antyukraińskiemu Związkowi Ochotników Donbasu.

18 Igor Girkin (Striełkow, ur. 1970) - w 1996-2013 pracownik FSB Rosji, zajmował się także rekonstrukcją wydarzeń historycznych, od 1998 był - podobnie jak Borodaj - korespondentenm impe- 
To są właśnie ci, którzy chcą sobie powalczyć, ręce ich swędzą... Wysłał ich na Krym w bardzo prostym celu, aby nie bałamucili Rosjan. Pojechali tam, a potem chcieli pojechać sobie jeszcze do Doniecka.

\section{„Przemieścili się”?}

Wyjechali z Krymu i są teraz w Doniecku - i Borodaj, i Striełkow. Z Krymem udało im się bardzo szybko, ale Donieck to nie Krym i nieprzypadkowo wielu przyrównuje ich teraz do Che Guevary, któremu udało się na Kubie, ale już nie w Boliwii. Przejechali do Doniecka i są praktycznie skazani na klęskę. Tam już im dadzą popalić...

\section{A co się z nimi stanie?}

Bardzo ciekawe pytanie. Możliwe, że zostaną zabici. I wtedy dla Putina problem zniknie.

\section{A kto miałby ich zabić?}

Oczywiście swoi, donieccy. Istnieje też możliwość, że wrócą do Rosji. I tutaj całkowitą rację ma Gleb Pawłowski ${ }^{19}$, który mówi, że Putin sam sobie wyhodował neoimperialną opozycję. Opozycję z lewa.

\section{Która powie, że nie posunął się tak daleko, jak było trzeba...}

I to jest właśnie najstraszniejsze. Dlatego, oczywiście, że tych ludzi nikt w Rosji nie wesprze, będzie tak samo, jak w Japonii, gdzie nikt nie wsparł Yukio Mishimy ${ }^{20}$.

rialno-nacjonalistycznej gazety „Zawtra”, wydawanej przez Aleksandra Prochanowa. W I992-1993 walczył jako ochotnik w Bośni po stronie Serbów, uzyskując od nich za swe monarchiczne poglądy przydomek „,carski oficer”. W 1998-2005 służył już jako realny oficer FSB w kaukaskich „zapalnych regionach” - w Dagestanie i Czeczenii. W 2013 zakończył służbę w FSB w randze pułkownika. Od 2014 - przywódca imperialistycznego ruchu „Noworosja”, szczególną sławę zyskał jako aktywny uczestnik zbrojnego konfliktu w Ukrainie wschodniej, m.in. w Słowiańsku. Od marca 2020 jeden z czterech obwinionych, sądzonych zaocznie w Amsterdamie za zastrzelenie nad Ukrainą I7 VII $20 I 4$ pasażerskiego samolotu Malezyjskich Linii Lotniczych (proces według przewidywań ma potrwać 4-5 lat). Obecnie Girkin, przebywając na emeryturze w Moskwie, krytykuje Putina za jego „brak zdecydowania” w stosunku do Ukrainy, którą Rosja winna była oczywiście zaanektować.

19 Gleb Pawłowski (ur. 195I) - dziennikarz i komentator polityczny, w czasach radzieckich dysydent, wydawał podziemną gazetę „Poiski” („Poszukiwania”). W 1982 aresztowany przez KGB i skazany na trzy lata zesłania do Republiki Komi, gdzie zarabiał na życie jako malarz pokojowy. W 1995-2009 współtworzył Fundację Efektywnej Polityki. Był doradcą Putina w jego pierwszej, jak dotąd, połowie rządów, jednakże wiosną 20II został wydalony z urzędu. Obecnie nieprzejednany krytyk prezydenta Rosji, w tym także jego agresywnej polityki wobec Ukrainy.

20 Yukio Mishima (1925-1970) - słynny japoński pisarz, propagujący kult ciała i bohaterskiej śmierci, autor m.in. powieści Wyznania maski (1949, wyd. pol. 2019) oraz tetralogii Ptodne morze (1968-1970). Trzykrotnie nominowany do Nagrody Nobla. Militarysta z krwi i kości, w 1967 odbył szkolenie wojskowe w Japońskich Siłach Samoobrony, a w 1968 został szefem paramilitarnego związku Stowarzyszenia Tarczy, które sam zakładał. Protestował przeciw pokojowemu statusowi Japonii po II wojnie, wzywał publicznie do zamachu stanu i przywrócenia silnej pozycji cesarza. Po całkowitej klęsce tych planów popełnił, przy pomocy uczniów, publiczne rytualne samobójstwo - „seppuku”. 
Ale ludzie ci narobią jeszcze wiele szumu, już się tam przecież rozhulali, premierami już nawet byli.

\section{Putin się ich pozbędzie, ludzie Putina?}

Nie sądzę... Przecież to się dzieje na oczach całego kraju. I ten kraj mówi, że to „nasi Rosjanie”...

A powiedz, te budynki w Bujnaksku, w Moskwie i Wołgodońsku, kto je wtedy wysadził $^{21}$, we wrześniu I999? To chyba nie Putin, jak mówiono wtedy w Polsce?

Nie... Oczywiście nie on... Bardzo łatwo to objaśnić. Pomysł, że Putin wysadzał domy, odpada już na samym starcie. Te eksplozje mogły zadziałać albo na korzyść Putina, albo przeciwko niemu. Tak się jednak złożyło, że kraj zjednoczył się po tych eksplozjach.

\section{Kto zatem wysadzat?}

Czeczeni, trzymani na pasku przez Federalną Służbę Bezpieczeństwa (FSB), tak samo jak w Biesłanie ${ }^{22}$.

\section{To znaczy rękami samego FSB?}

Nie, FSB wiedziało, ale nie aresztowało. Miało nadzieję, że potknie im się noga i że ich dopadną...

\section{Czyli oni, FSB, sądzili, że do eksplozji ostatecznie nie dojdzie?}

Oczywiście.... Byli pewni, że ci faceci, Czeczeni, są u nich na pasku, a okazało się, że nie... To, że Putin nie chciał tej eksplozji, jest dla mnie całkowicie oczywiste, ponieważ, logicznie rzecz ujmując, taka eksplozja miała zwrócić kraj przeciwko niemu, wywołać nienawiść do Putina. Zgotowałeś nam człowieku wojnę czeczeńską, a teraz wojna przyszła do Moskwy. Również i tutaj ma całkowitą rację Pawłowski, gdy mówi, że konsekwencje tych eksplozji były naprawdę nieprzewidywalne.

\section{A czy można mówić, że również i następne zamachy, akty terrorystyczne, także były w jakimś stopniu kontrolowane?}

21 Seria zamachów bombowych na budynki mieszkalne w czterech miasta Federacji Rosyjskiej, podczas których zginęło ponad trzysta osób. Zamachy, o które ówczesny premier Putin oskarżył czeczeńskich separatystów, a także inwazja tych ostatnich na Dagestan, wywołały falę strachu w całym kraju. W efekcie władze centralne rozpoczęły drugą wojnę czeczeńską, przy czym Putin uzyskał ogromną popularność, dzięki której w maju 2000 wygrał w cuglach wybory prezydenckie.

22 Biesłan - miasto w Osetii Północnej (Północny Kaukaz), w Federacji Rosyjskiej, piętnaście kilometrów od Władykaukazu. I września 2004 Szkoła Podstawowa nr I w Biesłanie stała się areną krwawej łaźni, jaką urządzili osetyjskim dzieciom i ich rodzicom czeczeńscy terroryści na polecenie Szamila Basajewa (1965-2006). Podczas walk zginęło ponad trzystu zakładników, w tym sto pięćdziesięcioro sześcioro dzieci, jeszcze więcej odniosło rany. Dodajmy, że ofiary były tradycyjnie prawosławne, a napastnicy wyznawali agresywny islam. 
Nie dopuszczam myśli, że kontrolował je Putin. Wiem, co wydarzyło się w Biesłanie, ponieważ w Biesłanie byłem. Tam pozwolili przejechać grupie bojowników, aby ją zaraz zatrzymać. Ale grupa skierowała się w inne miejsce. Myślano, że pojadą do centrum miasta, a oni skierowali się do szkoły, gdzie nikt się ich nie spodziewał. Ale w rzeczywistości to była grupa pod kontrolą, dlatego przepuszczano ich przez wszystkie posterunki. Teraz każdy pyta, jakże to oni mogli się przedostać, a to wszystko bardzo proste - przepuszczano ich tylko po to, aby nakryć. FSB myślało, że to ich własna prowokacja, ale prowokacja poszła dalej, niż mogli się spodziewać.

\section{A powiedz, Dymitrze, ile to już ról odegrał Putin od 1999 roku i czy jest to jego ostatnia rola?}

To niebanalne pytanie. Przyjrzyjmy się zatem, jakie role odgrywał. Po pierwsze, jak wszyscy inicjatorzy „zamrożenia”, Putin oficjalnie podkreśla kontynuację, swe dziedzictwo po Jelcynie, bo to przecież on posadził go na krześle. Stalin też cały czas powtarzał, że jest następcą Lenina, chociaż w praktyce ciągle go kwestionował. Oznacza to, że Putin na początku pełnił rolę stabilizującą, postrzegany był jako wielki terapeuta. Później jednak, jak wiemy, trzeba już zaproponować krajowi nowe cele, jakiś program pozytywny. Ponieważ jednak nie potrafi zaoferować programu intensywnego rozwoju, to proponuje teraz koncepcję „geopolityki”... Gdy jednak ktoś używa terminu „geopolityka”, to od razu możemy przestać z nim rozmawiać. To przecież bzdura, żadna „geopolityka” nie istnieje, dobrze o tym wiemy. Przedrostek "geo” jest czymś stałym, związanym z ziemią, a „polityka” - to sprawa intelektualna, w żaden sposób się to nie zgrywa. Ale teraz on ma właśnie pomysł na tak zwaną „geopolitykę" - czyli geopolityczny rozwój Rosji. Jest to idea ekspansji, wywierania nacisków, zdobywania nowych ziem... Zamiast - jak to słusznie mówi Michaił Chodorkowski ${ }^{23}$ - czynić życie znośnym na terytoriach już istniejących, to my musimy bez końca, ekstensywnie, nasze terytoria rozszerzać.

\section{Koncepcja już w carskiej Rosji dobrze znana...}

Tak, znana. Swoją drogą, Polska też była niegdyś częścią imperium rosyjskiego. Wczoraj, w krośnieńskim antykwariacie, przyglądałem się z zachwytem polskim książkom z rosyjską pieczęcią - „Dopuszczone do druku”24. Chcieliby to odzyskać, jak wiecie... Dlatego, oczywiście, idea ekspansji geopolitycznej nadal będzie funk-

23 Michaił Chodorkowski (ur. 1963) - rosyjski przedsiębiorca, w 1993 współzałożyciel słynnego „Jukosu” (wielkie przedsiębiorstwo naftowe), jeden z najbogatszych wówczas ludzi w Rosji. W $200 \mathrm{I}$ założył dobroczynną fundację Otwarta Rosja dla demokratycznych projektów kulturowych i edukacyjnych. Surowo krytykował prawie od początku politykę Putina. W 2003 - aresztowany, a w 2005 skazany na dziewięć lat łagru. 20 grudnia 2013 ułaskawiony przez Putina, wyjechał na Zachód jeszcze tego samego dnia. Mieszkał z rodziną w Szwajcarii, od 2016 - w Londynie. We wrześniu 20I4 ujawnił z emigracji swe ambicje prezydenckie, ale dziś - nadal krytykując bardzo ostro Putina - aktywną polityką już się nie zajmuje.

24 Dmitrij Bykow oglądał te książki w słynnym antykwariacie Zbigniewa Oprządka - w Krośnie, przy ulicy Wojciecha Portiusa, obok zabytkowego kościoła Św. Trójcy. 
cjonować. Jak dotąd, na tym szlaku mają tylko jeden sukces - Krym. Sukces raczej wątpliwy, ponieważ ani Krym, ani Rosja korzyści z tego mieć nie będą. Dalej Rosja już nigdzie się nie posunie... Nie ma dokąd.

A co się wydarzyło między Putinem-stabilizatorem a Putinem-geopolitykiem? I jaką rolę odegrała w tym Czeczenia? Wyjaśnię, co mówią o tym polscy przeciwnicy Putina. Putin, jak powiadają, od razu był taki sam, jakim jest teraz... postępował zawsze tak samo, ma ręce unurzane w czeczeńskiej krwi... a potem była jeszcze Gruzja. O tym właśnie mówił całej Europie prezydent Lech Kaczyński, że po Gruzji przyjdzie kolej na Ukrainę, potem na Polskę. Czy prezydent Kaczyński miał rację, że wojna Rosji z Gruzją w 2008 była wstępem do wojny Rosji z Ukrainą, co nastąpiło w 2014 roku, a następnie i do przyszłej wojny z Polską?

W kwestii Polski Kaczyński oczywiście się mylił...

\section{A w kwestii Ukrainy?}

Tu miał zdecydowanie rację.

Czyli że wtedy, w 2008, można już było przewidzieć na przykładzie Gruzji, co się stanie $z$ Ukrainą $w$ roku 2or4?

Można było... bo, wiecie, gdzie tkwi paradoks? Choć Gruzja i Ukraina sprawiły Rosjanom najwięcej problemów w całej postradzieckiej przestrzeni, to ideologicznie i kulturowo są one Rosji najbliższe. Bo przecież, mój Boże, nie z Azją Środkową, ideowo pozostającą w XV wieku, Rosja będzie się przyjaźnić.

Tak... czy też z Estonią...

Albo z Estonią, która w sensie ideowym, nie wiadomo, gdzie jest - w Europie, czy nie...

\section{Estonia jest w Estonii...}

A może nawet i w Estonii... Sęk w tym, że Gruzja i Rosja to kraje z bratnią kulturą, z więziami sportowymi, kulturowymi, rodzinnymi, niebywale sobie bliskie!

Muzyka, kino...

Właśnie... Stąd tak gniewne rozdrażnienie: „Jesteście przecież nasi!”

\section{A wojna między braćmi jest zawsze ostrzejsza...}

Otóż to - między braćmi. Gdyby to był Tadżykistan albo Uzbekistan Karimowa $^{25}$.. Przecież Putin ignorował absolutnie wszystko, co wyczyniał w Uzbekistanie Karimow. To jednak „tamci”, a „ci” to już rodzina, dlatego im nie wolno... Oczywiście, Ukraina musiała być następna, ale, tak samo jak Gruzja, oddzieli się ona teraz

25 Isłam Karimow (I938-20I6) - uzbecki prezydent-dyktator w czasach postradzieckich (I99I-20I6), wcześniej działacz komunistyczny. Dyskryminował w Uzbekistanie, przy całkowitym milczeniu 
od Rosji całkowicie. Potem zaś - wcześniej czy później - pojawi się tam prorosyjkki albo umiarkowany polityk, który będzie te więzi odbudowywać, ale, oczywiście, dawnymi Rosja i Ukraina już nigdy nie będą. Rosja utraciła Ukrainę na zawsze, trzeba się z tym pogodzić.

\section{A Krym pozostanie rosyjski?}

Nie, oczywiście, że nie. Ja tego nie mówię teraz dla wywiadu. Tego, proszę, może nawet nie drukujcie, ale oczywiście Krym nie zostanie rosyjski.

\section{Ale mówisz przecież o tym otwarcie w radiu „Echo Moskwy”.}

Mówię o tym otwarcie. Gdy Rosja będzie przechodzić, powiedzmy to na razie ostrożnie, przez te kolejne przemiany, a są one nieuniknione, wtedy oczywiście Krym stanie się albo autonomiczny, albo ukraiński. Z dużym prawdopodobieństwem Rosja rzeczywiście stanie się strukturą federalną. Pozostanie na mapie z dawnymi granicami, ale ustrój będzie inny, nie tak autorytarny, a wtedy i Krymu nikt już nie będzie trzymał.

\section{Kiedy wreszcie doczekamy się tego prawdziwego federalizmu?}

Oto jest pytanie. Przyniesie go nam Chodorkowski lub - całkiem możliwe - jakiś inny, doceniający wszystkie jej narody, lider Federacji Rosyjskiej...

\section{A krwawego przewrotu w najbliższym czasie w Rosji nie będzie?}

Pojęcia nie mam...

\section{To jaką rolę odegra Chodorkowski?}

Nie wiem... Obecny Chodorkowski jest dla mnie na razie niezbyt przejrzysty. Jako człowieka oceniam go bardzo dobrze, ale czego chce jako polityk, tego nie zdradza.

\section{Jest teraz na swoistej emeryturze...}

Ale uwierzcie... Na pewno będzie premierem Rosji.

To poczytaj sobie, co mówił w Polsce, na spotkaniu w redakcji „Gazety Wyborczej" ${ }^{\prime 26}$.

Przeróżne rzeczy mówi. W Polsce o jednym, w Ukrainie o drugim, a mnie - jeszcze co innego... Gdybyście tak zrobili wywiad z Leninem w Zurychu w i915... To by

26 W maju 2014 Michaił Chodorkowski otrzymał od „Gazety Wyborczej” tytuł Człowieka Roku 20I4. W redakcji odebrał osobiście kopię flagi z powstania listopadowego, którą Polacy w I83I uczcili pamięć dekabrystów. Laudację przygotował i wygłosił Leszek Balcerowicz. „GW” zorganizowała panel dyskusyjny o ówczesnej sytuacji na Ukrainie pt. Europa, Rosja, Ukraina. Prócz Chodorkowskiego, w rozmowie wzięli udział: brytyjski historyk i publicysta Timothy Garton Ash, były minister spraw wewnętrznych Ukrainy Jurij Łucenko, Andrej Sannikau - białoruski polityk, kandydat na prezydenta Białorusi, skazany przez Łukaszenkę na pięć lat kolonii karnej o zaostrzonym reżimie. Był też Dmitrij Muratow, redaktor naczelny moskiewskiej „Nowej Gazety”, którą prowadzący rozmowę Adam Michnik nazwał „głosem wolnej Rosji”. 
wam powiedział, że nawet jeszcze wnuki wasze żyć będą w carskim reżimie. Rosyjska historia powtarza się zawsze bardzo dokładnie, co do szczegółu. I premierem będzie ten, kto przebywa w Zurychu. Tak się ułożyło, geopolityka... Trzeba częściej sięgać do Lenina $w$ Zurychu Aleksandra Sołżenicyna ${ }^{27}$.

\section{A jednak Sołżenicyn nie został premierem, chociaż w Zurychu też przecież był...}

Sołżenicyn w Zurychu był gościem... a to już całkiem inna sprawa. Jeśli przeczytacie uważnie Lenina w Zurychu, to jego strategia przypomina co do szczegółu strategię Chodorkowskiego... Można różnie oceniać twórczość Sołżenicyna, ale praktycznie wszyscy przyznają, że Lenin $w$ Zurychu to jego najlepsze dzieło. Bohater przypomina autora. Sama Natalia Sołżenicyna ${ }^{28}$ nie ukrywa, że jest to praktycznie autoportret Sołżenicyna... A scena, gdzie Lenin występuje przed szwajcarskimi komunistami mówiąc, że Szwajcaria stanie się teraz centrum ruchu komunistycznego... To jest właśnie - wręcz dosłownie, co do szczegółu - wystąpienie Chodorkowskiego w Ukrainie. Podstawę tego zachowania filolog Aleksander Żołkowski widzi w wystąpieniu Ostapa Bendera przed szachistami w Wasiukach: „Stworzymy nowe Wasiuki!”29. Ta strategia Bendera jest obecna zarówno u Lenina, jak i u Chodorkowskiego. Chodorkowski będzie premierem Rosji... Dwa razy dwa jest cztery... Zwyczajnie jest mi wstyd, że niektórzy jeszcze tego nie pojmują...

27 Aleksander Sołżenicyn (1918-2008) - wielki rosyjski pisarz, więzień stalinowskich łagrów (19451953), autor odwilżowego Jednego dnia Iwana Denisowicza (196I), opublikowanego jeszcze w ZSRR za Chruszczowa oraz zdecydowanie już antyradzieckich, publikowanych na Zachodzie: Oddziatu chorych na raka (1968), Kreggu pierwszego (1969) i - epokowego - Archipelagu Gutag (1973-1975). W 1970 laureat literackiej Nagrody Nobla, którą władze radzieckie uznały za wymierzony jej policzek. W 1974-I994 - przymusowy emigrant, bezpaństwowiec (obywatelstwa radzieckiego go pozbawiono, innego zaś nie przyjął). W sierpniu I980 przysłał list strajkującym robotnikom Wybrzeża, dziękując za „wspaniały przykład, jakim dają narodom gnębionym przez komunistów”. $\mathrm{Na}$ emigracji trafił początkowo do Frankfurtu nad Menem, a wkrótce właśnie przejściowo do Zurychu. Opowieść Lenin w Zurychu (Paryż 1975) jest fragmentem większej całości pt. Sierpień I9I4, która z kolei stanowi pierwszy tom wielotomowej epopei Czerwone Koto.

28 Natalia Sołżenicyna (Swietłowa, ur. 1939) - druga żona pisarza, przeżyła wraz z nim trudne lata prześladowań i aresztowania (1968-1974), a następnie wszystkie lata emigracji i powtórnego pobytu w kraju, aż do śmierci męża (1994-2008). Od 1974 przewodniczy działającemu do dziś Funduszowi Sołżenicyna, udzielającemu pomocy pisarzom i ich rodzinom, prześladowanym przez różne współczesne reżimy. Wspaniała opiekunka nie tylko archiwum męża, ale i bardzo skuteczna propagatorka jego twórczości, przygotowała m.in. bardzo pożyteczną, skróconą wersję Archipelagu Gutag dla młodzieży szkolnej (2010). W maju 2018 gościła w Krakowie w murach Uniwersytetu Jagiellońskiego. W historycznej auli Collegium Maius wygłosiła odczyt z prezentacją o życiu i twórczości męża. Por. A. Nowakowski, Natalia Dmitrijewna Sotżenicyn. Zarys biograficzny, „Studia Pigoniana", 20I8, $\mathrm{nr}$ I, s. I47-I62.

29 W powieści Ilji Ilfa (1897-1937) i Jewgienija Pietrowa (1903-1942) pt. Dwanaście krzeset (1927) główny bohater, awanturnik Ostap Bender roztacza przed zachwyconymi mieszkańcami fikcyjnych Wasiuków wizję metropolii, jaką rzekomo ma się stać - dzięki zorganizowanym tam w przyszłości światowym turniejom szachowym - ich nadwołżańska, prowincjonalna mieścina. Jest to notabene jedna z najbardziej humorystycznych scen całej literatury rosyjskiej. 


\section{Powróćmy na ziemię... Jakie zmiany są nieuniknione latem 2014 w Rosji?}

No tak... ja wam teraz powiem, wy wydrukujecie i okaże się, że podżegam...

\section{No nie... mów śmiało...}

Decentralizacja na pewno, a to oznacza ogromne zmiany w systemie zarządzania krajem, dziś ten system jest wyłącznie wertykalny, absolutna piramida. A ona nie działa, bo biurokracja tłumi wszystko, co idzie z góry... Czyli to samo, o czym zawsze mówił Sołżenicyn - władza lokalna, na miejscu. Ziemstwa albo jakieś alternatywy ziemstwa, które włączają ludzi w system zarządzania krajem. Dokładnie to, co robi teraz w Jekaterynburgu Rojzman ${ }^{30}$, dlatego właśnie budzi on we władzach w Moskwie taką wściekłość, a przecież jest człowiekiem całkowicie propaństwowym, takie ma przekonania. Bynajmniej nie jest przeciwnikiem władzy centralnej, nie wychodził w Jekaterynburgu na demonstracje... Ale robi rzecz znacznie bardziej niebezpieczną - włącza mieszkańców do procesu zarządzania krajem.

\section{A ludzie tam są już do tego gotowi?}

Oczywiście, bo jak inaczej mógłby zostać wybrany? Czymże bowiem jest organizacja „Miasto bez narkotyków”, traktowana przez mieszkańców Jekaterynburga z takim uwielbieniem? To właśnie system samorządności miasta. Niestety, a raczej na szczęście, nie tylko w obszarze walki z narkomanią. Jak postrzegają Rojzmana w regionie? Tak jak Robin Hood pomagał potrzebującym podczas klęski głodu, stawał w obronie wdów i sierot - tak i Rojzman czyni coś podobnego. Czymże jest Sagra, ten słynny opór mieszkańców w wiosce pod Jekaterynburgiem, skąd wypędzono bandę najeźdźców? To także przecież jakiś samorząd ludowy ${ }^{31}$. No cóż, w Ameryce ludowe samorządy też przeszły przez etap samosądów, tzw. prawo Lyncha ${ }^{32}$. To był

30 Jewgienij Rojzman (ur. 1962) - rosyjski polityk i działacz społeczny, poeta, deputowany IV Dumy Federacji Rosyjskiej (2003-2007), od 2013 - prezydent (mer) Jekaterynburga na Środkowym Uralu. W 2018 podał się do dymisji w proteście przeciwko manipulacjom władzy centralnej. Za swego urzędowania walczył z handlem ze środkami odurzającymi pod hasłem „Miasto bez narkotyków”. Obecnie bardzo krytyczny wobec Putina, planował wziąć udział w wyborach do Dumy we wrześniu 2021, ale ostatecznie zrezygnował.

31 Konflikt w Sagrze - krwawe masowe starcie ze strzelaniną, I VII 20II, między mieszkańcami wioski Sagra, położonej czterdzieści kilometrów od Jekaterynburga, a międzynarodowym gangiem przybyłym właśnie z tego miasta. W wyniku strzelaniny zginął jeden z napastników, dwudziestoletni Faig Musajew, formalnie mieszkaniec Gruzji. Po apelu mieszkańców Sagry do organizacji „Miasto bez narkotyków” i po przekazie w internetowym „Żywym Żurnale” wydarzenie uzyskało międzynarodowy rozgłos.

32 Prawo Lyncha - samosąd wobec osoby podejrzanej o przestępstwo lub ciężkie naruszenie prawa, bez dochodzenia i procesu, dokonywane zwykle przez tłum uliczny, często przez powieszenie. Według jednej wersji, ów uliczny „akt sprawiedliwości” został tak nazwany w związku z nazwiskiem amerykańskiego sędziego Charlesa Lyncha, który inicjował tego rodzaju czyny podczas wojny o niepodległość Stanów Zjednoczonych (1775-1783). Według wersji drugiej - termin pochodzi od nazwiska kapitana Williama Lyncha, który w I780 roku wprowadził w Pensylwanii „ustawę Lyncha" o pozasądowych karach cielesnych, jednakże - nie karze śmierci. 
oczywiście tłum, mówią nawet, że Rojzman jest bandytą. Ale przepraszam... kto zrobił porządek w Ameryce na Dzikim Zachodzie? Bandyci robili porządek, po czym dopiero stopniowo zostali szeryfami. Jesteśmy z konieczności skazani na karuzelę samorządów. Nie zawsze legalnych, często nawet niezgodnych z prawem, ale organizowanych rękami samych ludzi.

\section{A kiedy się to wszystko uporządkuje, przeminie jedno pokolenie? Nie mówimy tu oczywiście o Jekaterynburgu, ale o całej Rosji. Powiedz, za jakieś dwadzieścia lat? Jeszcze za naszego życia?}

Ująłbym rzecz następująco: jest obecnie w Rosji paru ludzi, choćby Władimir Pastuchow, Siergiej Aleksaszenko ${ }^{33}$, czy też ja, którzy wiedzą, że wydarzy się to nieomal w najbliższej przyszłości. W ciągu roku, półtora, może dwóch, aż tak dokładnie to nie wiem. Jednak zdecydowana większość to pesymiści, mówiący: „To potrwa jeszcze dwadzieścia lat. Putin będzie rządził aż do 2034”. Panowie, jaki tu rok 2034? Problem w tym, czy on dotrwa do 2018? W I9I3 Cesarstwo Rosyjskie hucznie świętowało 300-lecie Domu Romanowów, a już 304-lecie obchodzono przy zupełnie innych dekoracjach.

\section{Sądzisz, że to nastąpi nieuchronnie?}

Minęło pięć lat i w I9I8 cała rodzina carska została rozstrzelana. Oczywiście w latach nieparzystych wszystko dzieje się delikatniej. Oczywiście, wszystko dokona się łagodnie. Zaszyje się Putin gdzieś za granicą i będzie spisywał wspomnienia.

\section{Dokądże wyjedzie?}

A to dopiero zagadka... Chcecie - to go sobie bierzcie.

\section{Na Kubę, do Syrii...?}

Nie, Kuba raczej nie... Myślę, że raczej Niemcy, dobrze zna niemiecki.

\section{Niemcy... brzmi ciekawie. Ale chyba potajemnie...}

Na razie nie wiadomo. Jawnie, niejawnie, różnie może być. Dziś to wielka niewiadoma. Nigdy nie potrafię przewidzieć konkretnych wydarzeń historycznych. Każdy

33 Władimir Pastuchow (ur. 1963) - politolog, publicysta, prawnik, mieszka w Londynie, pracownik naukowy University College London, stale współpracuje z moskiewskim radiem Echo Moskwy. Siergiej Aleksaszenko (ur. 1959) - w 1995-1998 wiceminister finansów Federacji Rosyjskiej i pierwszy wiceprzewodniczący zarządu Centralnego Banku Rosji, przeciwnik Putina. Od 2013 na emigracji, mieszka w Waszyngtonie. 2 maja 20I4 w radiu Echo Moskwy powiedział, że „Rosja swoimi działaniami na Krymie, poprzez zajęcie Krymu, naruszyła stan rzeczy, który rozwinął się w Europie”. We wrześniu 20I4 roku podpisał oświadczenie domagające się ,zakończenia agresywnej przygody: wycofania wojsk rosyjskich z terytorium Ukrainy i zaprzestania wsparcia propagandowego, materialnego i militarnego dla separatystów na południowym wschodzie Ukrainy”. W marcu 2020 podpisał protest przeciwko przyjęciu poprawek do Konstytucji Federacji Rosyjskiej autorstwa Putina, które umożliwiają Putinowi, wbrew przewidywaniom Bykowa, trwanie na urzędzie prezydenckim nawet i do 2036. 
się myli, gdy przepowiada konkrety. Ja potrafię przewidzieć tylko ogólny wektor, wiemy przecież, że on istnieje. Historia każdego kraju ma swój wektor nielinearny. W Ameryce na przykład to sinusoida ...

\section{A czy zgadzasz się z „teorią węzłów” Sołżenicyna, że istnieją takie etapy w hi- storii, gdy wydarzenia się „,zagęszczają” i możliwe są od tego momentu skrajnie różne wektory rozwoju?}

To, że istnieją „punkty węzłowe”, jest niezaprzeczalne. Sołżenicyn jest przecież matematykiem, nie zapominajmy o tym. Modele matematyczne to on konstruować potrafi. I trudno spierać się z Sołżenicynem w sprawach podstawowych. Na przykład, że samorząd terytorialny uratuje Rosję, etc. Ale już starego, powiedzmy, dojrzałego Sołżenicyna uwiódł ów urok władzy, to że Putin wzoruje się jakoby na Piotrze Stotypinie $^{34}$.

\section{Tak, Putin nadał Sołżenicynowi Nagrodę Państwową, a natychmiast potem odwiedził starego Sołżenicyna w jego domu.}

Odwiedził, dłoń mu ściskał... ${ }^{35}$

34 Piotr Stołypin (I862-I9II) - rosyjski polityk Rosji carskiej po I905 za Mikołaja II, trzeci z kolei premier ówczesnej Rosji oraz jej minister spraw wewnętrznych (I906-I9II). Podczas rewolucji 1905-1907 zasłynął okrucieństwem wobec „wichrzycieli”, organizując dla nich sądy polowe, które wydały ponad tysiąc wyroków śmierci, wykonywanych natychmiast przez powieszenie (stąd przywoływane niżej przez Bykowa określenie „krawat Stołypina”). Był zarazem reformatorem wsi rosyjskiej, zlikwidował archaiczną „obszczynę” (wspólnotę gminną na wsi), która skutecznie tłumiła gospodarkę rolną. Zorganizował też wielki plan przesiedleńczy dla bezrolnych chłopów z Rosji centralnej do Kraju Nadamurskiego, nadając im tam ziemię i ulgi podatkowe. I to właśnie doczekało się ze strony Sołżenicyna ogromnej aprobaty. Por. G. Przebinda, Aleksander Sotżenicyn na kresach Rosji, [w:] Literatura rosyjska. Nowe zjawiska. Reinterpretacje, „Prace Naukowe Uniwersytetu Śląskiego", nr 1539, Katowice I995, s. II8-I29. Stołypin zginął podczas zamachu w Kijowie, spoczywa w Ławrze Kijowsko-Pieczerskiej.

35 I2 czerwca 2007 Putin odznaczył Sołżenicyna za wielkie osiągnięcia w dziedzinie kultury Nagrodą Państwową, którą w Wielkim Pałacu Kremlowskim, w Sali św. Jerzego, odebrała za chorego pisarza jego żona Natalia. Następnie prezydent pojechał do domu Sołżenicynów w Troice-Łykowie pod Moskwą, gdzie pisarz opowiadał mu m.in. o Stołypinie i przywoływanym poniżej generale Ławrze Korniłowie, wskazując na wiszące na ścianie portrety ich obu. Korespondent moskiewskiej gazety „Kommiersant” pisał o tym z ironią: „Był to właśnie ów przypadek, gdy to nie góra przyszła do Mahometa, lecz Mahomet do góry. - Wysoko oceniam Pański przyjazd - powiedział pisarz - Ma Pan miliony obowiązków i trudno mi sobie nawet wyobrazić, że zdołał się Pan do mnie wybrać. - Władimir Putin nie zdecydował się zaprzeczać tym słowom. Podziękował pisarzowi za to, że ten „zgodził się go przyjąć”. Takiej wdzięczności Aleksander Sołżenicyn doczekał się jako pierwszy, jeśli się nie mylę, spośród wszystkich rozmówców Władimira Putina. - Zwróciłem uwagę pisarza, iż pewne akty, jakich teraz dokonujemy, współbrzmią dokładnie z tym, co pisał sam Sołżenicyn - powiedział Władimir Putin po spotkaniu. Należy żywić nadzieję, że miał on na myśli pracę Sołżenicyna Jak odbudować Rosję?, a nie jego Krag pierwszy”. А. В-Колесников, Александр Солженищьн принял Владимира Путина послучаю награждения Государственной премией России, „Коммерсантъ”, 2007, I3 VI, nr Ioo, s. 6. URL: https://www.kommersant.ru/ doc/773555 (dostęp 25.07.2021). 
Portret Korniłowa pisarz Putinowi pokazywat, a ten przyglądał się z taką uwagą... To dwaj moi główni bohaterowie Rosji, mówił Sołżenicyn - Piotr Stołypin i Ławr Kornilow ${ }^{36}$...

Moim zdaniem, jedyny błąd Sołżenicyna - a przeważnie się z nim zgadzam - to właśnie absolutyzacja Stołypina. My dziś już wiemy, że Stołypin reformatorem nie był. Nie da się przecież przeprowadzać reform ekonomicznych terrorem...

\section{Czyli, że Sołżenicyn wymyślił sobie Stołypina?}

Stworzył dla siebie jego model. Sam Stołypin uważał, że jest działaczem skazanym na zagładę, a Sołżenicyn traktuje go jako nadzieję dla Rosji. Sołżenicyn nie zrozumiał, albo też nie chciał zrozumieć, że nie jest możliwe reformowanie kraju przy jednoczesnym tłumieniu demokracji, wolności prasy - z użyciem metod represyjnych. W zbiorowej podświadomości narodowej, która notabene nigdy nie kłamie, Stołypin pozostał za sprawą dwóch rzeczy - więziennego wagonu zwanego stołypinowskim i takiego samego krawatu. A Stołypin jako „ojciec przesiedleńców” - to już jest Sołżenicyn...

\section{Też tak sądzimy...}

Ale jednak uściślę, że Sołżenicynowi możemy tu jednak jakoś zaufać. Stołypin, koniec końców, miał rozsądne pomysły: dajcie nam - mówił - dwadzieścia lat stabilnego rozwoju i będziemy liderem świata.

\section{Utopia... Bo co znaczył wtedy stabilny rozwój? I jeszcze - „Dajcie nam!”...}

No tak... to weźcie sobie sami! No... weźcie sobie... A wziąć się nie da, bo on wszystko tłumi, tłamsi okropnie... Tak było. Lenin właściwie miał rację co do Stołypina. Niestety, żaden przedstawiciel klasy ziemiańskiej nie może dokonać w Rosji przełomu. Kochamy walkę klas, czy też jej nie kochamy, ale tak już u nas jest.

Ale powiedz, może jednak Putin ma w swej głowie wyrzeźbioną wojnę? Nie o to chodzi, czego osobiście chce i czy dąży do tej wojny, ale chyba w jego głowie konflikt zbrojny naprawdę istnieje jako sposób działania. Nawet nie w tym sensie, że chodzi o rozszerzenie granic Rosji czy o zajęcie Kijowa...

Ale o strefy wpływów... tak, o strefy wpływów, ale pewnie także i ze strachu. Bo gdy nadejdzie czas i zobaczy, że bez wojny nie zdoła zachować władzy i życia, to wojna będzie. Dlatego wydaje mi się... moim zdaniem, to jest przede wszystkim niebezpieczne. Byłoby dobrze, osobiście czułbym się bezpiecznie, gdybym na pewno

36 Ławr Korniłow (1870-1918) - carski dowódca wojskowy, generał piechoty, bohater wojny rosyjsko-japońskiej 1904-I905 i I wojny światowej. Po rewolucji lutowej I9I7 naczelny wódz Armii Rosyjskiej (lipiec-sierpień 1917). Pod koniec sierpnia podjął nieudaną próbą obalenia rewolucyjnego Rządu Tymczasowego i wprowadzenia w Rosji dyktatury wojskowej („pucz Korniłowa”). Jednak próba zajęcia Piotrogrodu nie powiodła się, miasto zostało obronione m.in. przez bolszewików i kolejarzy, a także w wyniku nieposłuszeństwa w oddziale buntowników Korniłowa. Sam generał został uwięziony przez Kiereńskiego, ale zdołał uciec z twierdzy w Bychowie na wschodniej Białorusi. Zginął niedługo w bitwie o Jekaterynodar na Kubaniu, już podczas wojny domowej z bolszewikami. 
wiedział, że jeśli Niemcy przyjmą Putina, odnajdzie on tam azyl, wtedy nie będzie już tego jego strachu o życie, wyjedzie i zostawi nas w spokoju. Ale na razie, oczywiście, uważa on siebie za jedynego gwaranta stabilnego rozwoju Rosji.

\section{Ale czy nadejdzie czas, że i on zobaczy, że wszystko to runie?}

Być może. Ale na razie jest przekonany, że w Rosji bez niego natychmiast zapanuje krwawy chaos. A on jest tym ostatnim spoiwem kraju.

\section{A Chodorkowski też tak myśli o Putinie, jak on sam o sobie?}

Chodorkowski dopuszcza, że po Putinie może być jeszcze gorzej. Jedyne, co da się teraz zrobić, to przygotować kraj na jego odejście. Wypracować jakieś nawyki samorządności, znaleźć człowieka na miejsce Putina... Chodorkowski słusznie powiada, że teraz trzeba myśleć nie o tym, jak Putina obalić, ale co po nim będzie. Oto jest myśl! Tego jednak na razie nie wiadomo, co po nim będzie. Osobiście mam nadzieję, że nie nastąpi mimo wszystko chaos, przecież w terenie istnieje jakaś samorządność i Putin wcale nie jest tam dla wszystkich gwarantem stabilności. Znajdą się oczywiście ludzie, którzy będą głośno płakać po Putinie, tak jak płakali po Stalinie: „Co też teraz z nami będzie?!”... A z nami będzie życie, w którym sami zadecydujemy o sobie. Nie da się przecież żyć, gdy cały czas ktoś za ciebie decyduje, no nie da się... A to oznacza, według wszelkiego prawdopodobieństwa, że i my przeżyjemy jednak w Rosji okres demokratycznego rozwoju.

\section{Powiedz, proszę, kto z otoczenia Putina jest mu najbardziej wierny, a kto od razu go porzuci, natychmiast po tym, gdy zorientuje się, że Putin to już nie Putin?}

Bardzo słabo znam otoczenie Putina. Nigdy się w to nie wgłębiałem. Ale mam wrażenie, że wszyscy ludzie, których znamy dzisiaj jako „otoczenie Putina”, to oportuniści, konformiści. Będą się zmieniać tak samo, jak zmieniać się będzie historia. Ludzi absolutnie mu wiernych byłoby mi trudno wymienić. W każdym razie, wszyscy jego obecni propagandziści już przebyli tę krętą, ewolucyjną ścieżkę, od byłych dziennikarzy NTV ${ }^{37}$ po Władimira Sołowjowa, oczywiście tego dzisiejszego, a nie prawdziwego Władimira Sołowjowa ${ }^{38}$. Widać jak na dłoni, że ci ludzie wykazali całkowity, absolutny wręcz, brak pryncypiów. A to oznacza, że żaden z obecnych chwalców Putina, ani jego propagandystów, nie pozostanie dłużej w jego obozie. W tym sensie

37 NTV (stara) - rosyjska stacja telewizyjna z czasów Jelcyna. Powstała w 1993 i aż do maja 2000 była najbardziej profesjonalną i uczciwą telewizją Rosji. Jednakże Putin, po swej inauguracji prezydenckiej, rozpoczął z NTV wojnę i już w 200 została ona - oficjalnie „za długi” - przejęta przez Gazprom. Obecnie - właśnie wraz z krytykowanymi przez Bykowa niektórymi dziennikarzami z tego starego NTV - jest to tuba propagandowa Putina.

38 Władimir Siergiejewicz Sołowjow (I853-1900) - wielki rosyjski myśliciel-ekumenista, bliski notabene Janowi Pawłowi II (1920-2005). Por. G. Przebinda, Wtodzimierz Sotowjow wobec historii, Arka, Kraków 1992. Tenże, Większa Europa. Papież wobec Rosji i Ukrainy, Znak, Kraków 2002. Współczesny zaś Władimir Rudolfowicz Sołowjow (ur. 1963), to dziennikarz telewizyjny, wszechobecny w Internecie, niezwykle sprawny, pozbawiony wszelkich moralnych skrupułów propagandysta Putina. 
jest mi go nawet żal... będzie samotny. A kto z nim zostanie, tego nie wiem... Nie wiem też, jaki jest poziom poparcia dla niego wśród resortów siłowych. Ale myślę, że tylko motocykliści na czele z Załdostanowem ${ }^{39}$ stanowią jakąś proputinowską siłę, tylko zresztą dlatego, że mają oni bardzo ograniczone umysły.

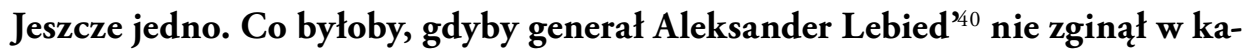
tastrofie powietrznej? Czy mógł on wcześniej czy później zostać prezydentem Rosji? Przecież Putin pojawił się całkiem przypadkowo, jak się powszechnie sądzi. Putin - człowiek bez właściwości, niczym w znanej powieści Musila... Powiadają, że był taki od samego początku.

Był i pozostał człowiekiem bez właściwości.

\section{Aż do tej pory?}

Przybiera taką formę, jaką...

\section{Putin-plazma...}

Jasne. On jest rzeczywiście plazmą. Przybiera tylko formę naczynia, do którego rzeczywistość go wlewa. Zupełnie przypadkowo odgrywa teraz historyczną rolę Napoleona.

No, ale powiedz, czy prezydentura generała Lebiedia była w ogóle realna? A może to tylko mit, utopia, że gdyby Lebied został spadkobiercą Jelcyna, byłoby w Rosji lepiej...

Jeszcze raz powtórzę: od jednostki w historii Rosji absolutnie nic nie zależy. Lebied' robiłby wszystko tak samo... Dokładnie tak samo robiłby Lebied'... Jedynie, co możliwe, byłby bardziej czarujący w swej roli, bez żadnych istotnych zmian... Pojawiłby się tutaj Primakow ${ }^{41}$ czy Ziuganow ${ }^{42}$ albo któryś z liberałów... to absolutnie bez znaczenia.

39 Aleksander Załdostanow (ur. 1963) - pseudonim „Chirurg”, były lekarz, obecnie lider rosyjskiego klubu motocyklowego i proputinowski działacz polityczny, przywódca Nocnych Wilków, największego klubu motocyklowego Rosji. Odznaczony przez Putina medalem „Za przywrócenie Krymu”.

40 Aleksander Lebied' (1950-2002) - oficer i polityk, uczestnik wojny afgańskiej, w I993 podczas konfliktu Jelcyna z Radą Najwyższą poparł tego pierwszego. W ogólnorosyjskich wyborach prezydenckich w 1996 zajął trzecie miejsce. W sierpniu 1996 doprowadził do zakończenia pierwszej wojny czeczeńskiej, którą określał jako „najbrudniejszą i najhaniebniejszą awanturę w dziejach naszego kraju”. Por. G. Przebinda, J. Smaga, dz. cyt., s. I58. W 1998-2002 gubernator Kraju Krasnojarskiego na Syberii Wschodniej. Zginął w katastrofie helikoptera w górach Sajanach nad Chakasją.

41 Jewgienij Primakow (I928-20I5) - polityk radziecki i rosyjski, znawca Bliskiego Wschodu, popierał wybór Gorbaczowa na sekretarza generalnego KPZR, za późnego Jelcyna - minister spraw zagranicznych (1996-1998) i premier Federacji Rosyjskiej (1998-I999). Za Putina żadnych wysokich funkcji nie pełnił, popierał jednakże ogólnie jego politykę.

42 Giennadij Ziuganow (ur. 1944) - przywódca Komunistycznej Partii Federacji Rosyjskiej, w ogólnorosyjskich wyborach prezydenckich 1996 roku rywalizował z Jelcynem. Ostatecznie przegrał, dopiero jednak po bardzo zaciętej walce, w której po stronie Jelcyna opowiedziały się skutecz- 


\section{A Krym również przy nich zostałby włączony do Rosji?}

Obawiam się, że tak. Ktokolwiek by to był...

\section{A że Krym jest teraz rosyjski, czy jest to rezultat zimowych wydarzeń na Majda- nie, podczas których obalono Wiktora Janukowycza? ${ }^{43}$ Gdyby jednak pozostał prezydentem, czy Krym do dziś byłby przy Ukrainie?}

Nie sądzę, raczej nie... Przecież żadna ukraińska władza, ani Juszczenko, ani Janukowycz, nie zrobiła nic, aby naprawdę zjednoczyć kraj. Żaden z nich nie uczynił niczego, aby Ukraina stała się jednością. A przecież Janukowycz, a przede wszystkim Juszczenko, mieli ku temu wszelkie szanse... „Dobrze - mógł przecież powiedzieć w 2004 roku Wiktor Juszczenko ${ }^{44}$ - to my wygraliśmy wybory, ale teraz żyjmy: wschód i zachód Ukrainy, Krym, wspólnie w jednym kraju”. Tylko tak... Ale nic z tych rzeczy.... Zwycięzcy dalej uparcie wbijali klin między wschodnią a zachodnią Ukrainą. No bo przyznawać order Banderze, czy to są metody porozumienia? Oczywiście, że to również ich, prezydentów Ukrainy, wina. I dlatego obawiam się, że każdy inny ewentualny prezydent Rosji powtarzałby wszystkie ruchy Putina. Historia posiada swą logikę, a żeby ta logika uległa zmianie, to Rosja musiałby przejść przez okres konstruktywnych reform. Musiałaby przekształcić się w państwo, gdzie w regionach sprawują władzę samorządy, a ludzie głosują realnie.

\section{Jesteś, jak wiemy, krytykowany zarówno w Rosji Putina, jak i w dzisiejszej} Ukrainie. Chociaż tam może teraz mniej niż kiedyś.

Chyba nie, zawsze mnie będą krytykować. Dla Rosjan jestem proukraińskim liberałem, a dla Ukraińców - wielkoruskim imperialistą.

nie wszystkie wielkie media Rosji. Potem jeszcze trzy razy (2000, 2008 i 20I2) rywalizował bez powodzenia - tylko jako tolerowana przez władze marionetka - o urząd prezydenta z Putinem i Dmitrijem Miedwiediewem (ur. 1965).

43 Wiktor Janukowycz (ur. 1950) - ukraiński polityk, w 2003-20Io lider prorosyjskiej Partii Regionów, w 2002-2005 i 2006-2007 premier Ukrainy, w 20I0-20I4-prezydent. W listopadzie 2013 odmówił podpisania, przygotowanego już nieomal co do przecinka, traktatu stowarzyszeniowego Ukrainy z Unią Europejską - na rzecz zacieśniania więzów Ukrainy z Rosją. W styczniu 2014 doprowadziło to do drugiej Pomarańczowej Rewolucji (Euromajdan), która w lutym 2014 obaliła Janukowycza, ale i przyczyniła się pośrednio już w marcu tego roku do zajęcia Krymu przez Rosję. Janukowycz zbiegł do Rosji, gdzie dotąd przebywa. W styczniu 2019 został zaocznie skazany przez ukraiński sąd - za zdradę stanu - na dziewięć lat więzienia.

44 Wiktor Juszczenko (ur. 1954) - w I999-200I premier Ukrainy, w 2005-2010 - prezydent. Wybory 2005 przeciwko Wiktorowi Janukowyczowi zdecydowanie wygrał, ale jego kontrkandydat - jako wpływowy wówczas premier - sfałszował wyniki i został nawet początkowo ogłoszony zwycięzcą. W efekcie doszło na Ukrainie do pierwszej Pomarańczowej Rewolucji, dzięki której Juszczenko objął jednak władzę. W styczniu 2oıo, już pod sam koniec pierwszej i ostatniej kadencji, nadał Stepanowi Banderze tytuł Bohatera Ukrainy „za niezłomny duch w służbie idei narodowej, bohaterstwo i poświęcenie w walce o niezależne państwo ukraińskie” oraz ogłosił dekret, uznający Ukraińską Powstańczą Armie UPA oraz Organizację Ukraińskich Nacjonalistów OUN „za uczestników walk o niepodległość Ukrainy”. 
A powiedz jeszcze... w wywiadzie, który przeprowadzaliśmy z tobą w Moskwie latem 2012 roku, padło nasze pytanie, co będzie właśnie z Ukrainą? ${ }^{45}$ Jak wiadomo, dla Polaków niezależne Ukraina, Litwa, Białoruś, są także rodzajem gwarancji dla demokracji i niepodległości samej Polski. Między Rosją a Polską leżą właśnie te trzy kraje, które powinny być niepodległe i demokratyczne, co oczywiście w przypadku Białorusi jest niestety dziś utopią. Ale powiedziałeś w tamtym wywiadzie, że osobiście nie wierzysz w zaistnienie Ukrainy jako odrębnego od Rosji demokratycznego państwa. I że Białoruś też nie będzie demokratyczna, co potwierdza się na naszych oczach. Problem w tym, czy jest to powód do radości, czy raczej do smutku?

Oczywiście, nie cieszy mnie to, co dzieje się teraz w samej Ukrainie. Jednak połączymy się wcześniej czy później w jakiś związek czy byt słowiański, jest to dla mnie oczywiste. Wcześniej czy później wolna Rosja będzie się przyjaźnić z wolną Ukrainą. Ale nie oznacza to, oczywiście, wspólnego państwa. Kiedyś Rosja, Ukraina i Białoruś będą stanowić jeden wspólny związek. Widzę to wyraźnie... Tyle tylko, że nie teraz... Teraz jest to absolutnie niemożliwe.

\section{Obecna sytuacja - to zjednoczenie fałszywe...}

Fałszywe. Bo dziś Ukraina odwraca się od Rosji plecami. Stara się istnieć jak najdalej od niej, Rosja jest dziś dla Ukrainy symbolem niewolnictwa. Jestem całkowicie przekonany, że gdyby Rosja zaczęła współpracować z Majdanem od razu, gdyby poparła Majdan i jeszcze wcześniej ukróciła Janukowycza, to wszystko mogłoby się potoczyć zupełnie inaczej. Ale oni od samego początku zaczęli głosić, że to faszystowska junta. I dlatego za wojnę domową na Ukrainie odpowiedzialne są, oczywiście, obie strony.

A podaj proszę, już na koniec, nazwiska dziesięciu pisarzy albo, powiedzmy, tytułów współczesnych książek rosyjskich, prócz oczywiście twoich, które teraz koniecznie powinniśmy przeczytać.

Denis Dragunski. Jego zbiory: Dorośli ludzie albo Zty chtopak. Jedno z dwóch. Następnie Michaił Uspienski z powieścią Rajska maszyna, napisał jeszcze Piekielna maszynę, chodzi o detonator, ale mam na myśli Rajska. Ksenia Buksza i jej Fabry$k a$ „Wolnośc’. Jest pół-Polką, Buksza to polskie słowo, na pewno was zainteresuje. Oczywiście, Zachar Prilepin, i to raczej Czarna matpa, choć Klasztor też jest dobry, ale Czarna matpa, moim zdaniem, lepsza... ciekawsza. Powieść autobiograficzna oraz Numer Jeden Ludmiły Pietruszewskiej. Wiktor Pielewin... tu tylko jedna jego powieść z ostatnich lat - Święta księga wilkołaka. Reszta, moim zdaniem, słabsza.

45 Rosjanin na rowerze, z Dmitrijem Bykowem, pisarzem, rozmawiają G. Przebinda i A. Wawrzyńczak, „Nowa Europa Wschodnia”, 2012, nr 5 (XXV), wrzesień-październik, s. 87-92. 


\section{Życie owadów też słabsze? To przecież wspaniała książka!}

Życie owadów to książka doskonała, ale powstała jeszcze w latach dziewięćdziesiątych. Tak... genialna książka, naprawdę... Dalej - Kassandra Michaiła Wellera. Powieść, a zarazem i niepowieść, książka publicystyczna, gdzie wszystko zostało przepowiedziane z absolutną precyzją. Dalej Władimir Szarow - Powrót do Egiptu. Maja Kuczerska Pateryk wspótczesny, ale to znacie, bo Kuczerska, o ile wiem, już u was gościła. Andriej Łazarczuk Inne niebo. I jeszcze bardzo istotna książka Mariny i Siergieja Diaczenków, a właściwie dwie ich ważne powieści, jedna Vita Nostra, a druga Brevis est-dylogia.

\section{Od 2013 mieszkają w Kalifornii...}

Tak, obecnie mieszkają w Stanach, ale naprawdę są ukraińskimi pisarzami, piszącymi po rosyjsku, trzeba ich koniecznie czytać. Któż jeszcze? Paweł Krusanow z Ukaszeniem aniota...

\section{To jeszcze rok 2000...}

Tak, ale od tego czasu niczego lepszego nie napisał... Premierę miały teraz jego opowiadania Król głowy, ale to nie jest dobra książka. I jeszcze Aleksander Szarow jego Incydent na nowym cmentarzu, stara powieść, ale wydrukowana dopiero teraz... Poczekajcie - Roman Sienczyn, jest taka powieść Informacja, to jego jedyna dobra rzecz, ale Sienczyna czytać pewnie trzeba, to taki „nowy realista”. I jeszcze Irina Łukjanowa $^{46}$, ale swoich chwalić - to grzech... a mimo to powiem - jej Szklana kula, wspaniała opowieść o radzieckim dzieciństwie, która zgarnęła wszystkie nagrody literackie, jakie tylko zdobyć było można...

\section{A poeci?}

Tak... Myślę, że wśród poetów najbardziej wartościowy jest Iwan Wołkow z Kostromy. Następnie Igor Karaułow, ten mieszka w Moskwie i, mimo że całkowicie oszalał na punkcie Krymu, stał się imperialistą, to dalej jest doskonałym poetą, polityka nie ma tu żadnego wpływu. Kto jeszcze...?

Porozmawiamy kiedyś o tym, a teraz powiedz, jakie są twoje trzy najlepsze książki, mamy oczywiście na myśli literaturę piękną.

Dzielnica... ŻD... Ostromow.

\section{A czwarta?}

Czwartej nie wymienię, na razie tylko te trzy...

46 Irina Łukjanowa (ur. 1959) - pierwsza żona pisarza, znana pisarka, m.in. autorka monografii (2007) o znanym pisarzu i tłumaczu Kornieju Czukowskim (I882-1969). W 20I0 odwiedziła wraz z Bykowem Kraków i Uniwersytet Jagielloński. Wspomniana Szklana kula ukazała się w 2012. 


\section{Ale po polsku wychodzi przecież właśnie Usprawiedliwienie.}

Usprawiedliwienie, no niech sobie wychodzi, to wczesna powieść, wszystko zatem po kolei.

\section{A gdzie szukać w Usprawiedliwieniu autorskiego punktu widzenia, o którym mówiłeś jako o tym ,innym”?}

Nadal uważam Usprawiedliwienie za dobrą powieść. Jednak jest ona walką z własnym kompleksem imperialnym. Od tego czasu jest on przezwyciężony, nie będę się już nim zajmował... Imperium oddziaływało na mnie jakiś swoim czarem, teraz to absolutnie nie działa. I właśnie dla walki z własnymi ideami imperialnymi napisałem to Usprawiedliwienie. Aby zwyczajnie dowieść, że to droga donikąd.

\section{Czyli, że jest to twoje własne Usprawiedliwienie?}

Własne-Moje Usprawiedliwienie, albo raczej- walka z samousprawiedliwianiem ${ }^{47}$.

Tłumaczyli pod opieką Grzegorza Przebindy: Kinga Bałon, Dominika Dyka, Mariola Jurczyk, Agnieszka Kupiec, Daria Starowiejska, Natalia Zajdel, Szymon Zajdel, Klaudia Zdzieba (studentki i studenci II roku dwujęzykowych studiów dla tłumaczy w Instytucie Humanistycznym Karpackiej Państwowej Uczelni im. Stanisław Pigonia w Krośnie).

47 Usprawiedliwienie wyszło w 2015 polsku jako Uniewinnienie. W swoim niedawnym, w miarę syntetycznym artykule o Bykowie polemizowałem z tym translatorskim wyborem: „Jednakże zdaniem Bykowa wszelkie poszukiwania logiki terroru prowadzą nieuchronnie do uznania jego racji, co też wielu niestety w dzisiejszej Rosji czyni. Dlatego kluczowy epizod jego powieści wygląda w autointerpretacji pisarza następująco: „Bohater Rogow widzi przed sobą, wydaje mu się, utopię łagier czystych ludzi w siole o nazwie Czyste, widzi tam przepiękną letnią polanę, biegnie po tej polanie i zwala się w straszne, śmierdzące grzęzawisko«. Ten obraz stanowił przestrogę również dla samego pisarza. Dlatego tytuł Usprawiedliwienie - a nie Uniewinnienie, jak w polskim przekładzie - winien być rozumiany dwojako. Po pierwsze w cudzysłowie, czyli ironicznie, jako polemika ze stalinistami w Rosji (także współczesnymi), poszukującymi patriotycznej logiki w masowych zbrodniach. Po drugie zaś, wprost - jako samousprawiedliwienie twórcy za odrzucony już podziw dla „sowieckiego projektu”. G. Przebinda, Dmitrij Bykow rozmraża Rosję, „Tygodnik Powszechny”, 2019, $20 \mathrm{X}, \mathrm{nr} 42$ (3667), s. I06. 
Putin-przeciętny menedżer z KGB

Rozmowa z Dmitrijem Bykowem (Krosno, maj 20I4)

Rozmowa z bardzo znanym pisarzem rosyjskim średniego pokolenia Dmitrijem Bykowem (ur. w 1967), przeprowadzona w Krośnie na Podkarpaciu w połowie maja 2014 roku, dotyczy sytuacji w Rosji oraz w Europie Wschodniej i Środkowowschodniej nazajutrz po aneksji ukraińskiego Krymu przez putinowską Rosję. Dmitrij Bykow opowiada się zdecydowanie przeciwko tej agresji, widząc w niej źródło wielu przyszłych nieszczęść Rosji, ale jednocześnie dostrzega też zgubny wymiar współczesnej polityki ukraińskiej, także - jego zdaniem - zanadto nacjonalistycznej. Gdy chodzi o ocenę funkcjonującego aż do dziś prezydenta Putina, to Bykow uznaje go za menedżera bardzo średniej klasy, a ogólnie - za człowieka bez właściwości, przepowiadając mu rychły upadek i emeryturę w jakimś zagranicznym kraju. Najciekawsze fragmenty rozmowy to jednak nie te, w których zostały sformułowane nieurzeczywistnione oczywiście przepowiednie pisarza, lecz te, w których mowa o przeszłych i aktualnych losach Rosji, która na początku XXI wieku znowu okazała się nieprzyjazna dla demokracji i dobrosąsiedzkich stosunków z bliższą i dalszą okolicą. Bykow widzi w tym swoiste rosyjskie „prawa historycznego rozwoju”, jednakże jego wizja przyszłych dziejów Ojczyzny jest daleka od fatalizmu i możemy ją nawet nazwać umiarkowanie optymistyczną.

\section{SŁOWA KLUCZOWE}

Dmitrij Bykow o aneksji Krymu przez Rosję Putina, Putin jako człowiek bez właściwości, pożytki z odrzucenia imperializmu przez Rosję, nacjonalistyczny aspekt współczesnej polityki Ukrainy

\section{ABSTRACT}

Putin - The Average KGB Manager

Interview with Dmitry Bykov (Krosno, May 20I4)

An interview with a very famous Russian writer of the middle generation, Dmitry Bykov (born in 1967), recorded in Krosno in the Subcarpathian region in mid-May 2014, concerns the situation in Russia and in Eastern and Central Europe shortly after the annexation of Ukrainian Crimea by Putin's Russia. Dmitry Bykov is strongly against this aggression, seeing it as the source of many future misfortunes for Russia, but at the same time he sees the disastrous dimension of contemporary Ukrainian politics, also - in his opinion - too nationalist. When it comes to the assessment of President Putin who functions to this day, Bykov considers him a very mediocre manager, and generally - a man without qualities, predicting his imminent collapse and retirement in some foreign country. The most interesting fragments 
of the conversation, however, are not those in which the writer's, of course, unfulfilled predictions were formulated, but those about the past and present fate of Russia, which at the beginning of the 2Ist century again turned out to be hostile to democracy and good relations with its closer and more distant neighbours. Bykov sees in this peculiar Russian "laws of historical development," but his vision of the future history of Russia is far from fatal and we can even call it moderately optimistic.

\section{KEY WORDS}

Dmitry Bykov on Russia's annexation of Crimea by Putin, Putin as a man without qualities, the benefits of Russia's rejection of imperialism, the nationalist aspect of contemporary Ukraine's policy 